\title{
Pneumonectomy of Primary Pulmonary Angiosarcoma with Malignant Effusion and Intrapleural Hypotonic Hyperthermic Chemotherapy: Case Report and Review of the Literature
}

\author{
Takanori Ayabe*, Masaki Tomita, Eiichi Chosa, Katsuya Kawagoe, \\ Kunihide Nakamura \\ Department of Surgery II, Faculty of Medicine, University of Miyazaki, Miyazaki, Japan \\ Email: ${ }^{*}$ tayabe@med.miyazaki-u.ac.jp
}

Received 11 January 2015; accepted 15 February 2015; published 17 February 2015

Copyright (C) 2015 by authors and Scientific Research Publishing Inc.

This work is licensed under the Creative Commons Attribution International License (CC BY).

http://creativecommons.org/licenses/by/4.0/

(c) () Open Access

\begin{abstract}
Background: Primary pulmonary angiosarcoma is extremely rare and the prognosis is very poor. We report a combination therapy of pneumonectomy and intrapleural hypotonic hyperthermic chemotherapy (IPHHC). Case report: A 48-year-old male with exertional dyspnea was found to have a left massive pleural effusion. Bronchoscopic examination displayed endobronchial stenosis of the left lower bronchus $B^{8,9,10}$ and diagnosed with pulmonary angiosarcoma. Chest computedtomographic scanning revealed a 5-cm mass in the left inferior lobe, which invaded the left upper bronchus. Intrapleural dissemination and malignant pleural effusion were also suspected (cT3N1M1a, c-stage IV). As a palliative initial therapy, we performed a pneumonectomy. On the $7^{\text {th }}$ postoperative day, under general anesthesia, we performed video-assisted IPHHC $\left(43^{\circ} \mathrm{C}, 60 \mathrm{~min}, 200 \mathrm{mg} / \mathrm{m}^{2}\right.$ of CDDP). After the IPHHC, there was no major adverse event (more than Grade 3) during the postoperative course. Histological examination of the resected specimen revealed a highly-cellular growth of atypical spindle cells with a storiform pattern. By immunohistochemical testing, the tumor cells stained positive for markers including CD31 and the factor VIII related antigen, and the diagnosis of pulmonary angiosarcoma was made. No adjuvant chemoradiotherapy was given, and the postoperative clinical course was uneventful. Although there had been a recurrence in the chest wall, the patient eventually died twenty-one months later. Conclusion: As a new therapeutic option, we performed IPHHC after the pneumonectomy for an advanced pulmonary angiosarcoma with malignant pleural effusion. Although the patient had a recurrence in the chest
\end{abstract}

\footnotetext{
${ }^{*}$ Corresponding author.
}

How to cite this paper: Ayabe, T., et al. (2015) Pneumonectomy of Primary Pulmonary Angiosarcoma with Malignant Effusion and Intrapleural Hypotonic Hyperthermic Chemotherapy: Case Report and Review of the Literature. Journal of Cancer Therapy, 6, 227-236. http://dx.doi.org/10.4236/jct.2015.62025 
wall, he had a reasonable postoperative outcome, that is, he returned to a work, retained a good quality of life and had a longer survival in spite of the poor prognosis of the pulmonary angiosarcoma.

\title{
Keywords
}

\author{
Pneumonectomy, Intrapleural, Hypotonic, Hyperthermic, Chemotherapy, Pulmonary \\ Angiosarcoma
}

\section{Introduction}

Primary pulmonary angiosarcoma is extremely rare and the prognosis is very poor. It can arise in any part of the body, such as the skin, heart, liver and breast [1]. The pulmonary angiosarcoma is usually the result of a metastatic disease, and its clinical features and the treatment course in the lung are not well known. Primary pulmonary angiosarcoma is characterized by an insidious growth with the tumor usually showing an extensive local invasion and haematogenous metastases by the time of presentation [2]. Early diagnosis is very rare because of a low recognition of differential diagnosis and a low grade of experience. Pulmonary angiosarcoma has a high rate of recurrence and is frequently disseminated at the time of diagnosis. As the tumor is foundinan advanced stage, it is difficult to make the appropriate radical treatment. There is no effective therapy except surgical resection of the pulmonary angiosarcoma. Chemotherapy and radiation therapy cannot be expected for the most effective therapy, however, multimodality therapy should be performed to manage the disease-control.

As a traditional therapeutic option for patients with malignant pleuritis, we developed intrapleural hyperthermic perfusion with chemotherapy (IPHC) using hyperthermic perfusion [3] [4]. The effectiveness of this traditional treatment was previously reported [3] [4]. IPHC, which includes the administration of cisplatin, resulted in enhanced anti-tumor effects [3]. For the present case, there was no curative treatment for the advanced pulmonary angiosarcoma with malignant pleural effusion, thus, we initially performed a palliative surgical resection of pneumonectomyin order to reduce the sarcoma-tumor volume. Next, instead of our traditional IPHC, as a new therapeutic option, we performed intrapleural hypotonic hyperthermic chemotherapy (IPHHC). The traditional IPHC regimen used an isotonic saline solution containing of cisplatin. On the other hand, in the case of the new IPHHC, instead of using a saline solution, we used distilled water for the dilution of cisplatin, which we expected to have an anti-tumor effect for the hypotonic cisplatin treatment [5]. According to Ichinose's experimental data [6], the hypotonic cisplatin solution showed a significantly stronger antitumor activity than the isotonic cisplatin solution.

The new IPHHC therapy had not been performed for lung cancer and malignant pleural mesothelioma by our department. For the first trial, we performed the new IPHHC treatment and we reported the results and the postoperative good outcome of the preserved quality of life and that a longer survival had been obtained.

\section{Case Report}

In June 2010, a 48-year-old male with exertional dyspnea was admitted to a hospital and a left massive pleural effusion was indicated on X-ray film (Figure 1). A chest drainage tube was inserted and hemorrhagic effusion was confirmed with a total volume of $1500 \mathrm{ml}$. However, the cytological examination showed no malignancy. A bronchoscopic examination revealed endobronchial stenosis of the left lower bronchus $B^{8,9,10}$ (Figure 2(A)) and slight discontinuous bleeding; the biopsy resulted in the diagnosis of pulmonary angiosarcoma. Extrabronchial invasion was suspected at the left main endobronchial membraneous portion (Figure 2(B)). In the right $\mathrm{B}^{6}$ (Figure 2(C)), a squamous cell carcinoma in situ was pathologically diagnosed, which had been under observation.

He was admitted to our hospital to receive a detailed examination and appropriate treatment. The results of the peripheral blood cells counts and biochemistry examinations were within normal limits. Tumor markers, including the carcinoembryonicantigen, cytokeratin 19 fragment and pro-gastrin-releasing peptide, were also within normal limits. Chest computed-tomographic scanning displayed a 5-cm mass in the left inferior lobe (Figure 3(A)), which obstructed the left lower endbronchus, and the lower lobe, except for the S6 segmental le- 


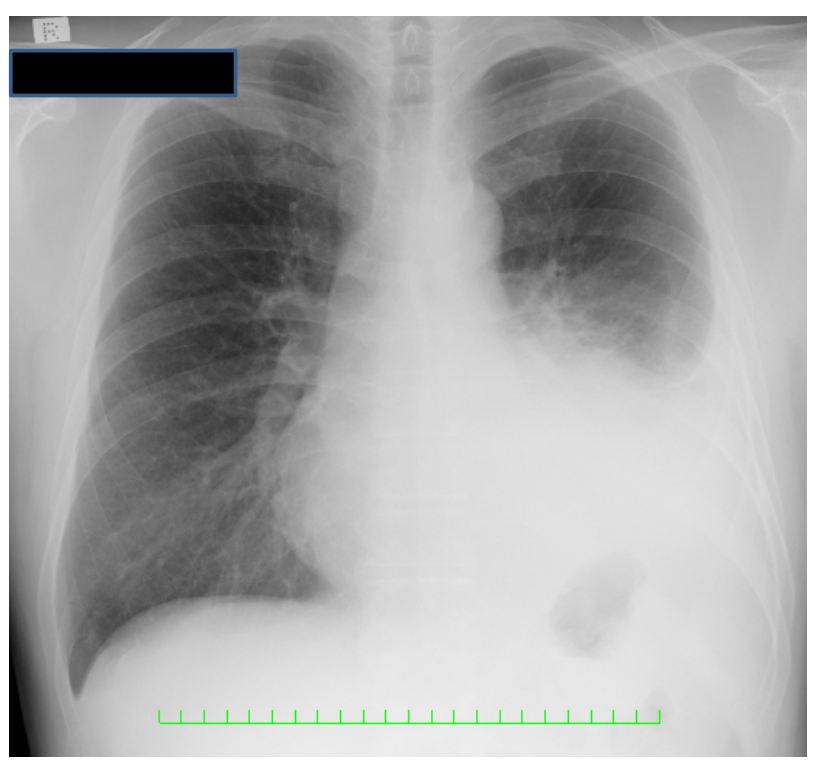

Figure 1. Chest X-ray showing the left massive pleural effusion.

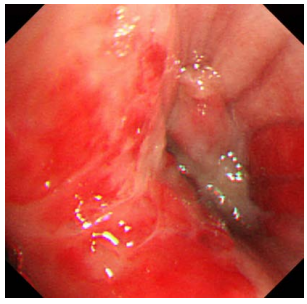

(A)

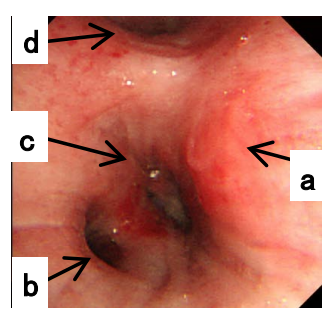

(B)

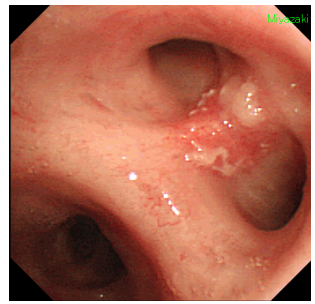

(C)

Figure 2. Bronchoscopic findings. (A) Endobronchial stenosis of the left lower bronchus $\mathrm{B}^{8,9,10}$; (B) Peribronchially, tumor invasion was suspected to the left main endobronchial membraneous portion. (a) Extrabronchial invasion to the left main endobronchial membraneous portion; (b) Normal $\mathrm{B}^{6}$ bronchus; (c) stenotic orifice of the left $\mathrm{B}^{8,9,10}$; (d) The left upper bronchus; (C) In situ squamous cell carcinomain the right $\mathrm{B}^{6}$.

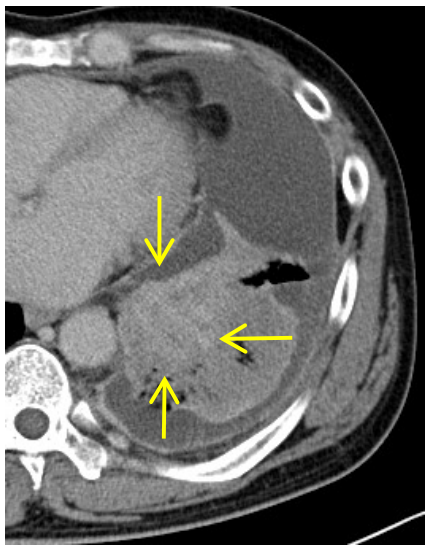

(A)

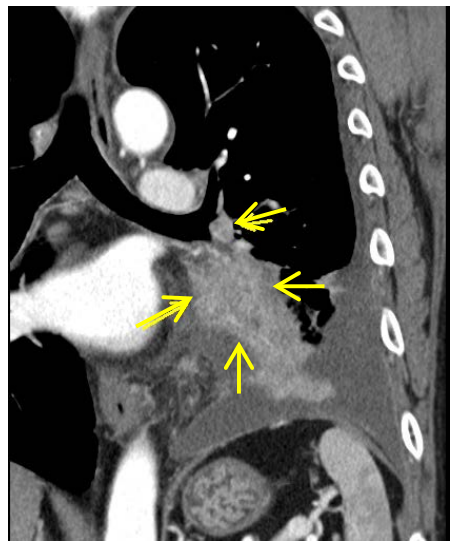

(B)

Figure 3. Chest computed-tomographic scanning. (A) The arrow shows a 5-cm mass, which obstructed the left lower endbronchus; (B) The arrows show that the tumor invaded the membraneous portion of the left main bronchus and the left upper bronchus with lymph nodal metastsis. 
sion, consisted of athelectasis and lymph nodal metastasis (N1+) (Figure 3(B)). The tumor was heterogeneously enhanced by a contrast agent, which continuously invaded the lingular segment of the left upper bronchus and the hilar lymph nodes, and which findings were suspected to invade the left upper lobe. Intrapleural dissemination and malignant pleural effusion were also suspected (cT3N1M1a, c-stage IV). Position emission topography displayed abnormal accumulations of the left hilar lymph nodes and the tumor in the basal part of the left inferior lobe (maximal standardized uptake valuemax, early: 7.0, delay: 9.1). There was no systemic distant metastasis.

As a palliative therapy, surgical resection with pneumonectomy for the primary pulmonary angiosarcoma and intrapleural hypotonic hyperthermic chemotherapy (IPHHC) were scheduled. The patient signed an informed consent. In November 2010, under general anesthesia, one-lung ventilation, after the left open thoracotomy at the $5^{\text {th }}$ intercostal space, the intraoperative cytology of pleural effusion resulted in a negative malignancy findings. Prompt intraoperative pathological examination showed a positive malignancy at the edge of the bronchial stump and disclosed tumor-cell-invasions of the pericardial fat tissue and pleura. The picking-up of mediastinal lymph nodes (station \#8) showed a positive metastasis (N2+, pT3N2M1a, p-stage IV). Although the patient had suffered small daily discontinuous hemoptysis, we performed a left pneumonectomy to remove the pulmonary tumorous bleeding origin. We performed a blood transfusion of red cell concentrates of mannitol adenine phosphate (4 units) and fresh-frozen plasma (2 units). The specimen showed a pleural dissemination of the surface of the resected lung (Figure 4(A) and Figure 4(B)).

On the $7^{\text {th }}$ postoperative day after the initial pneumonectomy operation, we performed IPHHC $\left(43^{\circ} \mathrm{C}, 60 \mathrm{~min}\right.$, $200 \mathrm{mg} / \mathrm{m}^{2}$ of CDDP), the therapy of which was based on the modified methods from the previous reports of Matzuzaki et al. [3] [4]. Under general anesthesia, IPHHC was performed under video-assisted thoracic surgery. After removal of the thoracic drainage tube, a thoracovideoscope was inserted in the left pleural cavity. Prior to the hyperthermic perfusion therapy in the left empty thorax, the postoperative residual hematoma and pleural effusion containing tumor cells were removed as much as possible, then two inflow and outflow tubes were placed in the pleural cavity, which were connected to a specially devised circuit (modified CRPH-3000C, MERA, Ltd.). As previously reported [3] [4], with traditional IPHC therapy, the thoracic cavity is irrigated for 2 hours with a $43^{\circ} \mathrm{C}$ isotonic saline solution (3000 mL) containing $200 \mathrm{mg} / \mathrm{m}^{2}$ of CDDP. In the newly developed therapy of IPHHC, we used distilled water (as a hypotonic dilution solution) instead of an isotonic saline solution, which modified the perfusion method is called intrapleural hyotonic hyperthermic chemotherapy (IPHHC). The IPHHC was performed using almost the same method as in Matsuzaki et al.'s previous reports [3] except for the use of distilled water instead of a saline solution, which was expected to have a triple synergistic effectiveness of hypotonic, cisplatin-cytotoxic and hypertherrmic anti-tumor effects on the tumor cells, which is a new therapeutic concept based on the combination of Matsuzaki et al.'s [3] and Ichinose et al.'s [5] reports. The thoracic cavity was irrigated for $1 \mathrm{~h}$ with a $43^{\circ} \mathrm{C}$ hypotonic solution (3000 mL) containing $200 \mathrm{mg} / \mathrm{m}^{2}$ of CDDP (Figure 5(A) and Figure 5(B)). At the end of the perfusion, all fluids in the thoracic cavity were removed. The cytologies of the pleural effusion before and after the IPHHC both showed negative findings of malignant cells. After the IPHHC treatment, there was no major adverse event (more than Grade 3) in the postoperative course. There had been observed a Grade 2 anemia and Grade 1 liver dysfunction. On the postoperative Day 14, the thoracic drainage tube was removed, and the cytology of the drainage effusion showed a negative finding of malignant cells. The in situ squamous cell carcinoma in the right endobronchus had been under observation.

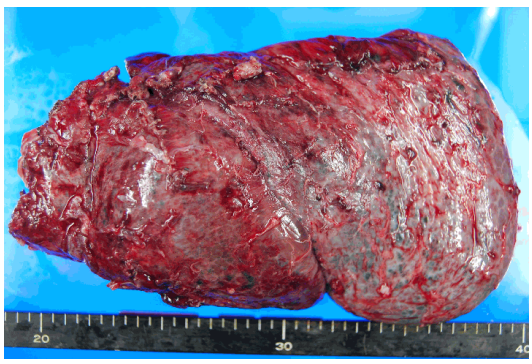

(A)

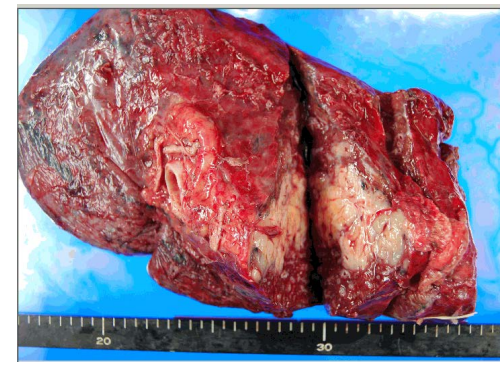

(B)

Figure 4. Macroscopic findings of the resected specimen. (A) The surface of the left lung had a multiple pleural dissemination (M1a); (B) The left main bronchial stump edge was pathologically positive and the hilar lymph nodal metastasis was confirmed (N1+). 


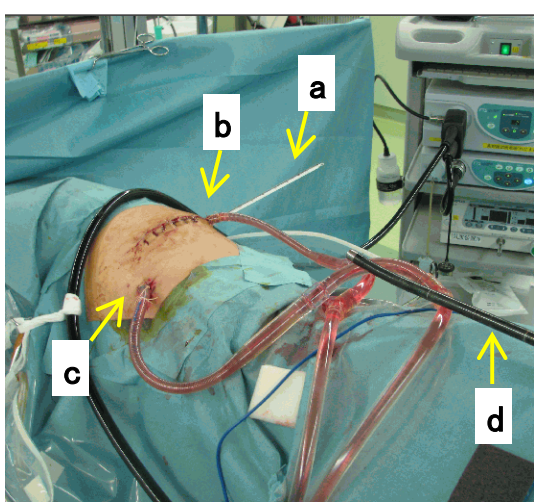

(A)

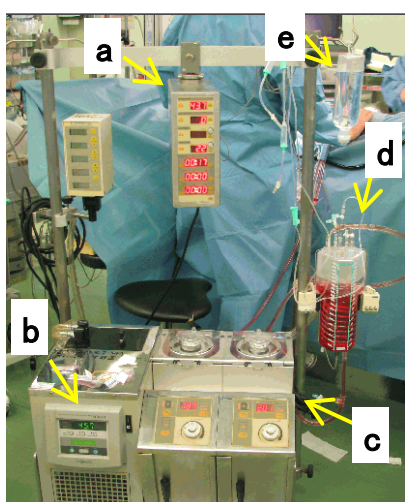

(B)

Figure 5. Intraoperative perfusion system of intrapleural hypotonic hyperthermic chemotherapy (IPHHC) perfusion system ((A) and (B)). (A) Intraoperative right side lying position under general anesthesia. The initial left posterolateral thoracotomic incision scar was observed. a: Intrapleural thermometer; b: Inflow tube; c: Outflow tube; d: Thoracoscopy. (B) Intrapleural hyperthermic perfusion system. a: Monitoring of intracircuit temperature; b: Incubator; c: Two roller pumps for inflow and outflow; d: Circuit reservoir; e: Drip infusion to the reservoir.

Histological examination of the resected specimen revealed a highly-cellular growth of atypical spindle cells with a storiform pattern (Figure 6(A)). These atypical cells showed a relatively low mitotic activity. There was extensive intra-alveolar hemorrhage. Upon immunohistochemical testing using a standard avidin-biotin technique, the tumor cells stained positively for markers including CD31 (Figure 6(B)) and the factor VIII related antigen (vVF/Factor VIII) (Figure 6(C)), and negative for the anti-cytokeratin (CK7, CK20), CD34, D2-40, epithelial membrane antigen, smooth muscle actin, surfactant AP, and HMB45. The diagnosis of the primary pulmonary angiosarcoma was made. The postoperative clinical course was uneventful.

No adjuvant chemoradiation therapy was given and he returned to work as a self-employed person. The patient had a good, preserved quality of life and longer postoperative lifetime, however, there had been a recurrence in the chest wall. He eventually died twenty-one months later.

\section{Discussion}

Primary pulmonary angiosarcoma is extremely rare. Angiosarcoma is a type of malignant vascular tumor characterized by the proliferation of neoplastic cells with vascular endothelial features, accounting for only $1 \%-2 \%$ of all soft tissue sarcomas [1]. An angiosarcoma found in the lung most likely represents metastasis from a primary tumor of the skin, heart, breast, and liver [1]. We found two review reports in the English literature [7] [8]. Based on these reports, we reconstructed the listed cases and added our case, which consisted of a total of 22 cases as shown in Table 1 [2] [7] [9]-[27]. From the review summary of Table 1, epidemiologically, the mean average age was $52.1 \pm 14$.2-year-old (range, 23 - 79). Twenty males (90.9\%) were affected more often than two females $(9.1 \%)$ by a ratio of 10:1. The characteristics of the clinical symptom are related to respiratory problems, that is hemoptysis, chest pain, dyspnea, and cough. Hemoptysis was found in 10 cases (45.4\%).

A definitive diagnosis of the pulmonary angiosarcoma was made on the basis of our histopathological and immunohistochemical findings [28]. At first, a bronchoscope, and if possible, a surgical biopsy, are the most effective diagnostic methods. Histologically, these tumors are characterized by infiltrative lesions composed of sheets of large oval or round cells with abundant eosinophilic nucleoli. Althought cytological atypia is present, the tumor cells are relatively monomorphic. Mitosis, necrosis and haemorrhage are common findings. An immunohistochemical examination was essential for the diagnosis; the neoplastic cells showed a reactivity for endothelial cell markers (CD31, CD34, factor VIII and Ulex europaeus agglutinin I), epithelial markers (cytokeratins and sometimes EMA) and vimentin [25].

For the treatment and prognosis, there have been few reports of an effective treatment for this pulmonary angiosarcoma. Surgical resection, radiation, chemotherapy and immunotherapy have all been attempted (Table 1), but none of them have been shown to be significantly effective [19] [22]. Surgery has been the main treatment, even though this highly aggressive tumor is usually inoperative at the time of diagnosis [17] [29]. Several pre- 
Table 1. Literature review of primary pulmonary angiosarcoma.

\begin{tabular}{|c|c|c|c|c|c|c|c|}
\hline $\begin{array}{l}\text { Case } \\
\text { No. }\end{array}$ & Author (yr) & Gender & $\begin{array}{l}\text { Age } \\
\text { (yr) }\end{array}$ & Symptoms (time) & Therapy & $\begin{array}{l}\text { Survival } \\
\text { (months) }\end{array}$ & Reference \\
\hline 1 & $\begin{array}{l}\text { Castleman, B., } \\
\text { et al., } 1954\end{array}$ & M & 48 & Hemoptysis & - & 1 & [9] \\
\hline 2 & $\begin{array}{l}\text { Tralka, G.A., } \\
\text { et al., } 1963\end{array}$ & M & 64 & $\begin{array}{l}\text { Chest pain, shortness } \\
\text { of breath, malaise }\end{array}$ & Supportive care & 1 & [10] \\
\hline 3 & $\begin{array}{l}\text { Spragg, R.G., } \\
\text { et al., } 1983\end{array}$ & M & 75 & Dyspnea, malaise & Steroid & $<1$ & [11] \\
\hline 4 & $\begin{array}{l}\text { Ott, R.A., } \\
\text { et al., } 1987\end{array}$ & M & 60 & $\begin{array}{l}\text { Shortness of } \\
\text { breath (3 months) }\end{array}$ & Rt. pneumonectomy & 2 & [12] \\
\hline 5 & $\begin{array}{l}\text { Palvio, D.H., } \\
\text { et al., } 1987\end{array}$ & M & 59 & Hemoptysis, chest pain & Surgery & $<1$ & [13] \\
\hline 6 & $\begin{array}{l}\text { Segal, } \\
\text { et al., } 1988\end{array}$ & $\mathrm{~F}$ & 72 & Malaise, dyspnea & Steroid & $<1$ & [14] \\
\hline 7 & $\begin{array}{l}\text { Sheppard, M.N., } \\
\text { et al., } 1997\end{array}$ & M & 65 & Hemoptysis (3 months) & Steroid & $<1$ & [15] \\
\hline 8 & $\begin{array}{l}\text { Junge, K., } \\
\text { et al., } 2001\end{array}$ & M & 41 & $\begin{array}{l}\text { Shortness of } \\
\text { breath (6 months) }\end{array}$ & $\begin{array}{c}\text { Neoadjuvant } \mathrm{CT}^{*} / \mathrm{RT}^{* *}+ \\
\text { Lt. lower lobectomy }+ \\
\text { Adjuvant } \mathrm{CT}^{*} / \mathrm{RT}^{* *}\end{array}$ & Alive & [16] \\
\hline 9 & $\begin{array}{l}\text { Atasoy, C., } \\
\text { et al., } 2001\end{array}$ & M & 50 & $\begin{array}{l}\text { Chest pain, malaise, and } \\
\text { hoarseness ( } 2 \text { months) }\end{array}$ & $\mathrm{CT}^{*}$ & 9 & [17] \\
\hline 10 & $\begin{array}{l}\text { Kojima, K., } \\
\text { et al., } 2003\end{array}$ & M & 25 & $\begin{array}{l}\text { Chest pain, cough, } \\
\text { shortness of breath, } \\
\text { weight loss ( } 1 \text { month) }\end{array}$ & $\mathrm{RT}^{* *}+$ Interleukin-2 & $\begin{array}{c}\text { Alive } \\
\text { (1-year follow-up) }\end{array}$ & [18] \\
\hline 11 & $\begin{array}{l}\text { Maglaras, G.C., } \\
\text { et al., } 2004\end{array}$ & M & 46 & Hemoptysis & $\mathrm{CT}^{*}$ & 1 & [19] \\
\hline 12 & $\begin{array}{l}\text { Pandit, S.A., } \\
\text { et al., } 2005\end{array}$ & $\mathrm{~F}$ & 79 & $\begin{array}{l}\text { Chest pain, } \\
\text { shortness of breath }\end{array}$ & Supportive care & 18 & [20] \\
\hline 13 & $\begin{array}{l}\text { Corpa-Rodriguez, } \\
\quad \text { et al., } 2005\end{array}$ & M & 42 & Chest pain, cough & $\begin{array}{l}\text { Rt. upper lobectomy with } \\
\text { chest wall resection }+ \\
\text { Adjuvant } \mathrm{CT}^{*} / \mathrm{RT}^{* *}\end{array}$ & 2 & [21] \\
\hline 14 & $\begin{array}{l}\text { Bouhaouala, } \\
\text { M.H., et al., } 2005\end{array}$ & M & 46 & Hemoptysis (6 months) & Rt. lower lobectomy & 11 & [22] \\
\hline 15 & $\begin{array}{l}\text { Ozcelik, C., } \\
\text { et al., } 2006\end{array}$ & M & 62 & $\begin{array}{l}\text { Hemoptysis, chest pain, } \\
\text { cough, shortness of breath, } \\
\text { weight loss ( } 5 \text { months) }\end{array}$ & $\begin{array}{l}\text { Rt. upper lobectomy }+ \\
\text { Adjuvant } \mathrm{CT}^{*} / \mathrm{RT}^{* *}\end{array}$ & 5 & [23] \\
\hline 16 & $\begin{array}{l}\text { Herrak, L., } \\
\text { et al., } 2007\end{array}$ & M & 48 & $\begin{array}{l}\text { Chest pain, } \\
\text { cough (3 months) }\end{array}$ & Refused treatment & - & [24] \\
\hline 17 & $\begin{array}{l}\text { Wilson, R., } \\
\text { et al., } 2008\end{array}$ & M & 56 & $\begin{array}{l}\text { Hemoptysis, chest pain, } \\
\text { cough, shortness of } \\
\text { breath, weight loss }\end{array}$ & $\begin{array}{l}\text { Lt. upper lobectomy }+ \\
\text { Adjuvant } \mathrm{CT}^{*} / \mathrm{RT}^{* *}\end{array}$ & 39 & [25] \\
\hline 18 & $\begin{array}{l}\text { Kuroda, N., } \\
\text { et al., } 2009\end{array}$ & M & 43 & Cough & Lt. lower lobectomy & $\begin{array}{l}\text { Alive (15-month } \\
\text { follow-up) }\end{array}$ & [26] \\
\hline 19 & $\begin{array}{l}\text { Chen, Y.B., } \\
\text { et al., } 2010\end{array}$ & M & 50 & Hemoptysis (2 months) & $\mathrm{CT}^{*}$ & Alive & {$[2]$} \\
\hline 20 & $\begin{array}{l}\text { Wan Musa, W.R., } \\
\text { et al., } 2010\end{array}$ & M & 23 & $\begin{array}{l}\text { Shoulder pain, chest pain, } \\
\text { shortness of breath, } \\
\text { weight loss ( } 6 \text { months) }\end{array}$ & $\mathrm{CT}^{*}$ & 4 & [27] \\
\hline 21 & $\begin{array}{l}\text { Kakegawa, S., } \\
\text { et al., } 2011\end{array}$ & M & 45 & Hemoptysis & Lt. pneumonectomy & $\begin{array}{c}\text { Alive } \\
\text { (1-year follow-up) }\end{array}$ & [7] \\
\hline 22 & $\begin{array}{l}\text { Ayabe, T., } \\
\text { et al., } 2015\end{array}$ & M & 48 & $\begin{array}{l}\text { Shortness of breath, } \\
\text { pleural effusion }\end{array}$ & $\begin{array}{l}\text { Lt. pneumonectomy + } \\
\text { Intrathoracic hypotonic } \\
\text { hyperthermic } \\
\text { chemotherapyy }\end{array}$ & 21 & Our case \\
\hline
\end{tabular}

\footnotetext{
${ }^{*}$ Computed tomography; ${ }^{* *}$ Radiation therapy.
} 


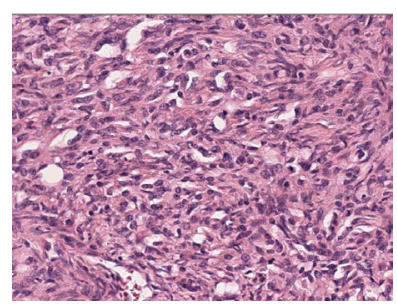

(a)

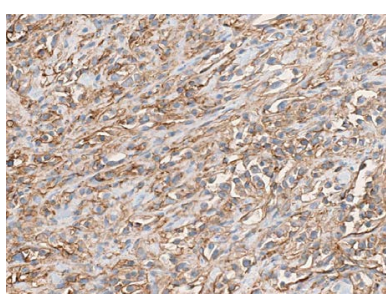

(b)

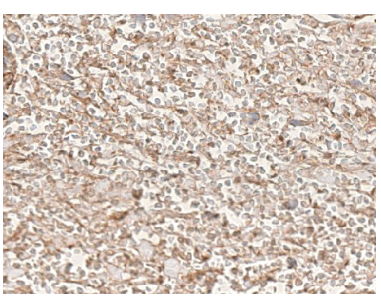

(c)

Figure 6. (A) Histological examination of the specimen showed highly cellular growth of atypical spindle cells with storiform pattern (Hematoxylin and Eosin staining) (B) and (C). Immunohistochemical staining using a standard avidin-biotin technique; the tumor cells were positively stained for the markers, including CD31 (B) and Factor VIII-related antigen (vVF/ Factor VIII) (C).

vious studies have demonstrated that angiosarcoma is radiosensitive [17]. Chemotherapy is almost exclusively used as a palliative treatment. Clinical responses have been associated with various chemotherapeutics, the most common regimens were doxorubicine, ifosfamide, taxanes and sorafenib [30]-[33]. Therapeutic modalities, such as radiotherapy, as angiosarcomas have been found to be radiosensitive, while chemotherapy has also been described [24]. In addition, our case had a 21-month long survival, however, Wilson et al. reported a longer survival of 39 months [25]. Wilson et al. reported a complete radiographic response by adjuvant chemotherapy of gemcitabine and taxotere for the recurrence of multiple bone metastases after a left upper lobectomy for the N2-IIIA stage of pulmonary angiosarcoma [25]. There was a difference in the treatment modality, surgical procedure and adjuvant therapy between the two cases, at least, not only surgery, but also adjuvant therapy should be done to extend the patient's survival.

The systemic administration of high doses of recombinant interleukin 2 (rIL-2) seems to have been effective [17]. However, there is no known treatment to be totally effective. To date, multimodality therapy, such as surgery for resectable tumors, radiotherapy, chemotherapy and immunotherapy, should be performed to provide a good disease-control.

Unfortunately, the prognosis of pulmonary angiosarcoma is very poor and the mortality is very high. After the diagnosis of the angiosarcoma, and any treatment, almost all patients are dead within one year [17] [22] [32] [34]. Based on our review (Table 1), the median overall survival was 8.0 months (160 months, $n=20$ ). However, patients who underwent surgery had a longer median survival of 12.6 months (113 months, $n=9$ ).

As a palliative therapy, we performed IPHHC after a pneumonoectomy for the advanced pulmonary angiosarcoma with malignant effusion. In cases of advanced lung cancer with malignant effusion, to control the pleural effusion and to preserve the patient's better quality of life, we sometimes performed a traditional intrapleural hyperthermic chemotherapy (IPHC) as a palliative therapy [3] [4]. Regarding the IPHHC therapy, there have been no previous reports. For the traditional IPHC treatment, there is also no appropriate clinical trial for the tumor response rate and overall survival. This time, the new IPHHC was our first clinical practice for thoracic malignant diseases involving of pulmonary angiosarcoma.

Generally, the aim of the traditional IPHC is the synergistic effectiveness of both the anti-tumor effect of cisplatin and hyperthermic damage to malignant tumor cells. On the other hand, the aim of the new IPHHC is the synergistic effectiveness of the triple concept of hypotonic, hyperthermic, and anti-tumor effects for malignant tumor cells. Based on this concept, a clinical trial of IPHC and/or IPHHC treatments should be considered in the future. However, clinically, in practice, the IPHC therapy has been performed for unresectable tumors with malignant pleural effusion, even though which therapy should become one of the expected therapies for sarcomapatients with no effective therapy has not been determined. There are no reports of IPHHC for pulmonary angiosarcoma, however, this treatment strategy might be applicable for other forms of cancer except for lung cancer.

For the anti-cancer effectiveness of hyperthermia, generally, 1) tumor cells have a high hyperthermic sensitivity compared to those of normal cells, 2) tumor tissues have a high hyperthermic sensitivity selectively dependent on the specificity of the surrounding tissue-environment (low $\mathrm{pH}$, hypoxic, fragility of tumor angiogenesis), 3) high hyperthermic sensitivity in the latter phase of synthesis in the cell cycle, and 4) enhancement of the sensitivity of anti-cancer drugs for cancer cells have been performed as a combination therapy with radiation and 
chemotherapy.

On the other hand, for the anti-cancer effectiveness of the hypotonic solution perfusion with cisplatin, the hypotonic cisplatin solution demonstrated a significantly greater anti-tumor activity than isotonic cisplatin [6]. The intrapleural hypotonic cisplatin solution environment should damage both the tumor and normal cells compared to the intrathoracic isotonic surroundings. Because the difference inosmotic pressure on the outside and inside of the tumor cell membrane, water and cisplatin are thought to easily enter the tumor cell, which should have resulted in much higher cell-toxicity, in addition, this hyperthermic condition should also produce much stronger synergistic anti-tumor effects.

The mechanism by which the hypotonic cisplatin treatment shows an anti-tumor effect is considered as follows: 1) distilled water itself has a direct cytotoxicity; 2) tumor cells exposed to the hypotonic cisplatin increase their cellular cisplatin level since the cells become swollen by the hypotonic solution; and 3) species such as chloro-aqua and diaqua, which are formed by the hydrolysis of cisplatin in the distilled water, are also believed to be active anti-tumor agents. Thus, the intrapleural hypotonic cisplatin treatment using cisplatin and distilled water is thought to have a synergistic anti-tumor effect which might result in a high local control rate and the disappearance of cancer cells in the drainage fluid after the operation in patients with carcinomatous pleuritis found during a thoracotomy.

We performed a palliative pneumonectomy of unresectable pulmonary angiosarcoma. The reason was to reduce the angiosarcoma volume and to prevent lethal pulmonary bleeding from the tumor. Because there were few effective therapies for pulmonary angiosarcoma, we selected a combination therapy of palliative surgical resection and IPHHC. For the residual disseminated intrathoracic sarcoma cells, as a local intrathoracic therapy, in addition to the effect of hyperthermic damage and sarcoma-cell cell injury, we used the perfusion solution of distilled water. During the postoperative hospitalization, there was no significant adverse event more than Grade 3. The patient's survival after the treatment was 21 months, as a palliative and intrapleural local therapy for thoracic malignancies with pleural effusion, the IPHHC therapy should be one of the considered therapies.

\section{Conclusion}

For the treatment of primary pulmonary angiosarcoma, there are few therapies except for surgery, as there has been reported to be almost no effectiveness of chemotherapy and irradiation therapy. However, we performed a palliative pneumonectomy of advanced pulmonary angiosarcoma with malignant pleural effusion and IPHHC treatment. Although the patient had a postoperative recurrence in the chest wall, he had a reasonable postoperative outcome such as temporary preservation of his quality of life and a longer survival of 21 months in spite of the poor prognosis.

\section{References}

[1] Patel, A.M. and Ryu, J.H. (1993) Angiosarcoma in the Lung. Chest, 103, 1531-1535. http://dx.doi.org/10.1378/chest.103.5.1531

[2] Chen, Y.B., Guo, L.C., Yang, L., et al. (2010) Angiosarcoma of the Lung: 2 Cases Report and Literature Reviewed. Lung Cancer, 70, 352-356. http://dx.doi.org/10.1016/j.lungcan.2010.09.002

[3] Matsuzaki, Y., Shibata, K., Yoshioka, M., Inoue, M., Sekiya, R., Onitsuka, T., Iwamoto, I. and Koga, Y. (1995) Intrapleural Perfusion Hyperthermo-Chemotherapy for Malignant Pleural Dissemination and Effusion. Annals of Thoracic Surgery, 59, 127-131. http://dx.doi.org/10.1016/0003-4975(94)00614-D

[4] Matsuzaki, Y., Edagawa, M., Shimizu, T., Hara, M., Tomita, M., Ayabe, T. and Onitsuka, T. (2004) Intrapleural Hyperthermic Perfusion with Chemotherapy Increases Apoptosis in Malignant Pleuritis. Annals of Thoracic Surgery, 78, 1769-1772. http://dx.doi.org/10.1016/j.athoracsur.2004.05.025

[5] Ichinose, Y., Tsuchiya, R., Koike, T., Yasumitsu, T., Nakamura, K., Tada, H., Yoshimura, H., Mitsudomi, T., Nakagawa, K., Yokoi, K. and Kato, H. (2002) A Prematurely Terminated Phase III Trial of Intraoperative Intrapleural Hypotonic Cisplatin Treatment in Patients with Resected Non-Small Cell Lung Cancer with Positive Pleural Lavage Cytology: The Incidence of Carcinomatous Pleuritis after Surgical Intervention. The Journal of Thoracic and Cardiovascular Surgery, 123, 695-699. http://dx.doi.org/10.1067/mtc.2002.120712

[6] Ichinose, Y., Hara, N., Ohta, M., Asoh, H., Yano, T., Maeda, K. and Yagawa, K. (1993) Hypotonic Cisplatin Treatment for Carcinomatous Pleuritis Found at Thoracotomy in Patients with Lung Cancer. In Vitro Experiments and Preliminary Clinical Results. Journal of Thoracicand Cardiovascular Surgery, 105, 1041-1046.

[7] Kakegawa, S., Kawashima, O., Ibe, T., Ujita, M., Iwashina, M., Nakano, T. and Shimizu, K. (2012) A Case of Primary 
Angiosarcoma of the Lung Presenting as a Hemorrhagic Bronchial Tumor. Annals of Thoracic and Cardiovascular Surgery, 18, 347-351. http://dx.doi.org/10.5761/atcs.cr.11.01716

[8] Obeso Carillo, G.A., García Fontán, E.M., Cañizares Carretero, M.Á. and Pérez Pedrosa, A. (2013) Primary Pulmonary Angiosarcoma, an Exceptional Neoplasm with a Poor Prognosis: Reports of Two Cases and Review of the Literature. General Thoracic and Cardiovascular Surgery, 61, 643-647. http://dx.doi.org/10.1007/s11748-012-0200-6

[9] Case 40191 (1954) Case Records of the Massachusetts General Hospital: Weekly Clinicopathological Exercises. New England Journal of Medicine, 250, 837-841. http://dx.doi.org/10.1056/NEJM195405132501909

[10] Tralka, G.A. and Katz, S. (1963) Hemangioendothelioma of the Lung. American Review of Respiratory Disease, 87, 107-115.

[11] Spragg, R.G., Wolf, P.L., Haghighi, P., Abraham, J.L. and Astarita, R.W. (1983) Angiosarcoma of the Lung with Fatal Pulmonary Hemorrhage. The American Journal of Medicine, 74, 1072-1076. http://dx.doi.org/10.1016/0002-9343(83)90821-5

[12] Ott, R.A., Eugene, J., Kollin, J., Kanas, R.J., Conston, D.E. and Chi, J.C.H. (1987) Primary Pulmonary Angiosarcoma Associated with Multiple Synchronous Neoplasms. Journal of Surgical Oncology, 35, 269-276. http://dx.doi.org/10.1002/jso.2930350413

[13] Palvio, D.H., Paulsen, S.M. and Henneberg, E.W. (1987) Primary Angiosarcoma of the Lung Presenting as Intractable Hemoptysis. The Thoracic and Cardiovascular Surgeon, 35, 105-107. http://dx.doi.org/10.1055/s-2007-1020207

[14] Segal, S.L., Lenchner, G.S., Cichelli, A.V., Promisloff, R.A., Hofman, W.I. and Baiocchi, G.A. (1988) Angiosarcoma Presenting as Diffuse Alveolar Hemorrhage. Chest, 94, 214-216. http://dx.doi.org/10.1378/chest.94.1.214

[15] Sheppard, M.N., Hansell, D.M., Du Bois, R.M. and Nicholson, A.G. (1997) Primary Epithelioid Angiosarcoma of the Lung Presenting as Pulmonary Hemorrhage. Human Pathology, 28, 383-385. http://dx.doi.org/10.1016/S0046-8177(97)90140-4

[16] Junge, K., Toens, C., Peiper, C., Hermanns, B. and Schumpelick, V. (2001) Primary Angiosarcoma of the Lung. Der Chirurg, 72, 969-972. http://dx.doi.org/10.1007/s001040170098

[17] Atasoy, C., Fitoz, S., Yigit, H., Atasoy, P., Erden, I. and Akyar, S. (2001) Radiographic, CT, and MRI Findings in Primary Pulmonary Angiosarcoma. Clinical Imaging, 25, 337-340. http://dx.doi.org/10.1016/S0899-7071(01)00302-3

[18] Kojima, K., Okamoto, I., Ushijima, S., Yoshinaga, T., Kitaoka, M., Suga, M. and Sasaki, Y. (2003) Successful Treatment of Primary Pulmonary Angiosarcoma. Chest, 124, 2397-2400. http://dx.doi.org/10.1378/chest.124.6.2397

[19] Maglaras, G.C., Katsenos, S., Kakadelis, J., Katsanos, C., Metafratzi, Z., Stefanou, D.G., Vassiliou, M.P. and Constantopoulos, S.H. (2004) Primary Angiosarcoma of the Lung and Pleura. Monaldi Archives for Chest Disease, 61, 234-236.

[20] Pandit, S.A., Fiedler, P.N. and Westcott, J.L. (2005) Primary Angiosarcoma of the Lung. Annals of Diagnostic Pathology, 9, 302-304. http://dx.doi.org/10.1016/j.anndiagpath.2005.04.001

[21] Corpa-Rodríguez, M.E., Mayoralas-Alises, S., García-Sánchez, J., Gil-Alonso, J.L., Díaz-Agero, P. and Casillas-Pajuelo, M. (2005) Postoperative Course in 7 Cases of Primary Sarcoma of the Lung. Archivos de Bronconeumología, 41, 634-637. http://dx.doi.org/10.1157/13081253

[22] Bouhaouala, M.H., Charfi, M.R., Fajraoui, N., Bouaziz, N., Boukhris, A. and Kilani, T. (2005) Angiosarcome Pulmonaire Primitive. Primary Pulmonary Angiosarcoma. Revue de Pneumologie Clinique, 61, 115-118. http://dx.doi.org/10.1016/S0761-8417(05)84798-4

[23] Ozcelik, C., Onat, S., Yaldiz, M. and Ozcelik, Z. (2006) Primary Epithelioid Angiosarcoma of the Lung Presenting as Pulmonary Hemorrhage. Asian Cardiovascular and Thoracic Annals, 14, 69-71. http://dx.doi.org/10.1177/021849230601400118

[24] Herrak, L., Alaziz, S. and Benosmane, A. (2007) Primary Pulmonary Angiosarcoma. Revue des Maladies Respiratoires, 24, 73-76. http://dx.doi.org/10.1016/S0761-8425(07)91015-3

[25] Wilson, R., Glaros, S., Brown, R.K., Michael, C. and Reisman, D. (2008) Complete Radiographic Response of Primary Pulmonary Angiosarcomas Following Gemcitabine and Taxotere. Lung Cancer, 61, 131-136. http://dx.doi.org/10.1016/j.lungcan.2007.12.006

[26] Kuroda, N., Hamaguchi, N., Inoue, K., Ohara, M., Mizuno, K., Hayashi, Y. and Lee, G.H. (2009) Application of Immunocytochemistry to the Diagnosis of Primary Epithelioid Angiosarcoma of the Lung. Medical Molecular Morphology, 42, 250-253. http://dx.doi.org/10.1007/s00795-008-0417-8

[27] Wan Musa, W.R., Abdulwakil Elraied, M.A., Phang, K.S., Kwah, Y.G., Tan, S.P., Harun, R. and Ban, A.Y. (2010) Primary Epithelioid Angiosarcoma of the Lung Presenting as Left-Sided Shoulder Pain. Annals of the Academy of Medicine, Singapore, 39, 658-659.

[28] Weissferdt, A. and Moran, C.A. (2010) Primary Vascular Tumors of the Lungs: A Review. Annals of Diagnostic Pa- 
thology, 14, 296-308. http://dx.doi.org/10.1016/j.anndiagpath.2010.03.001

[29] Sasaki, R., Soejima, T., Kishi, K., Imajo, Y., Hirota, S., Kamikonya, N., Murakami, M., Kawabe, T., Ejima, Y., Matsumoto, A. and Sugimura, K. (2002) Angiosarcoma Treated with Radiotherapy: Impact of Tumor Type and Size on Outcome. International Journal of Radiation Oncology, Biology, Physics, 52, 1032-1040. http://dx.doi.org/10.1016/S0360-3016(01)02753-5

[30] Fayette, J., Martin, E., Piperno-Neumann, S., Le Cesne, A., Robert, C., Bonvalot, S., Ranchère, D., Pouillart, P., Coindre, J.M. and Blay, J.Y. (2007) Angiosarcomas, a Heterogeneous Group of Sarcomas with Specific Behavior Depending on Primary Site: A Retrospective Study of 161 Cases. Annals of Oncology, 18, 2030-2036. http://dx.doi.org/10.1093/annonc/mdm381

[31] Donghi, D., Dummer, R. and Cozzio, A. (2010) Complete Remission in a Patient with Multifocal Metastatic Cutaneous Angiosarcoma with a Combination of Paclitaxel and Sorafenib. British Journal of Dermatology, 162, 697-699. http://dx.doi.org/10.1111/j.1365-2133.2009.09607.x

[32] Penel, N., Bui, B.N., Bay, J.O., Cupissol, D., Ray-Coquard, I., Piperno-Neumann, S., Kerbrat, P., Fournier, C., Taieb, S., Jimenez, M., Isambert, N., Peyrade, F., Chevreau, C., Bompas, E., Brain, E.G. and Blay, J.Y. (2008) Phase II Trial of Weekly Paclitaxel for Unresectable Angiosarcoma: The ANGIOTAX Study. Journal of Clinical Oncology, 26, 5269-5274. http://dx.doi.org/10.1200/JCO.2008.17.3146

[33] Yamada, M., Hatta, N., Mizuno, M., Oishi, N. and Takehara, K. (2005) Weekly Low-Dose Docetaxel in the Treatment of Lung Metastases from Angiosarcoma of the Head. British Journal of Dermatology, 152, 811-812. http://dx.doi.org/10.1111/j.1365-2133.2005.06503.x

[34] Girard, N., Barbareschi, M., Cordier, J.F. and Murer, B. (2007) What Is a Rare Tumour and How Should It Be Dealt with Clinically? Pathology of the Lung by W. Timens and H. H. Popper. European Respiratory Society Monographs, 86-134. http://dx.doi.org/10.1183/1025448x.00039005

\section{Abbreviations}

IPHC: Intrapleural Hyperthermic Chemotherapy

IPHHC: Intrapleural Hypotonic Hyperthermic Chemotherapy 
Scientific Research Publishing (SCIRP) is one of the largest Open Access journal publishers. It is currently publishing more than 200 open access, online, peer-reviewed journals covering a wide range of academic disciplines. SCIRP serves the worldwide academic communities and contributes to the progress and application of science with its publication.

Other selected journals from SCIRP are listed as below. Submit your manuscript to us via either submit@scirp.org or Online Submission Portal.
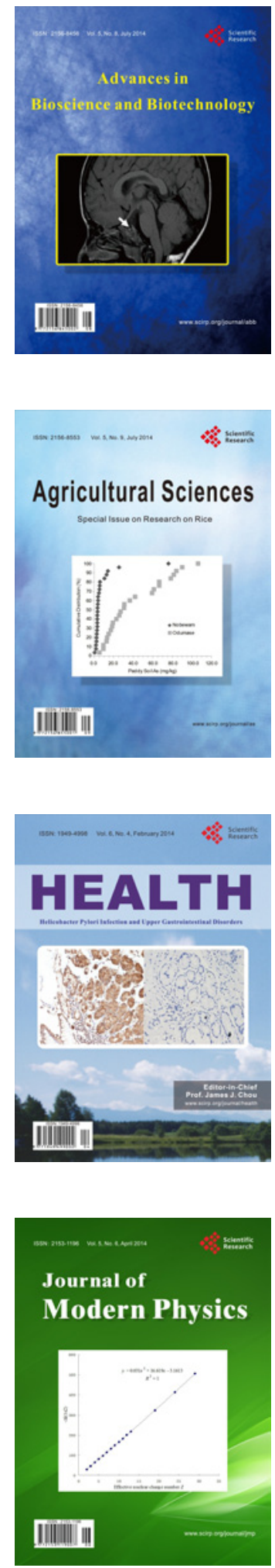
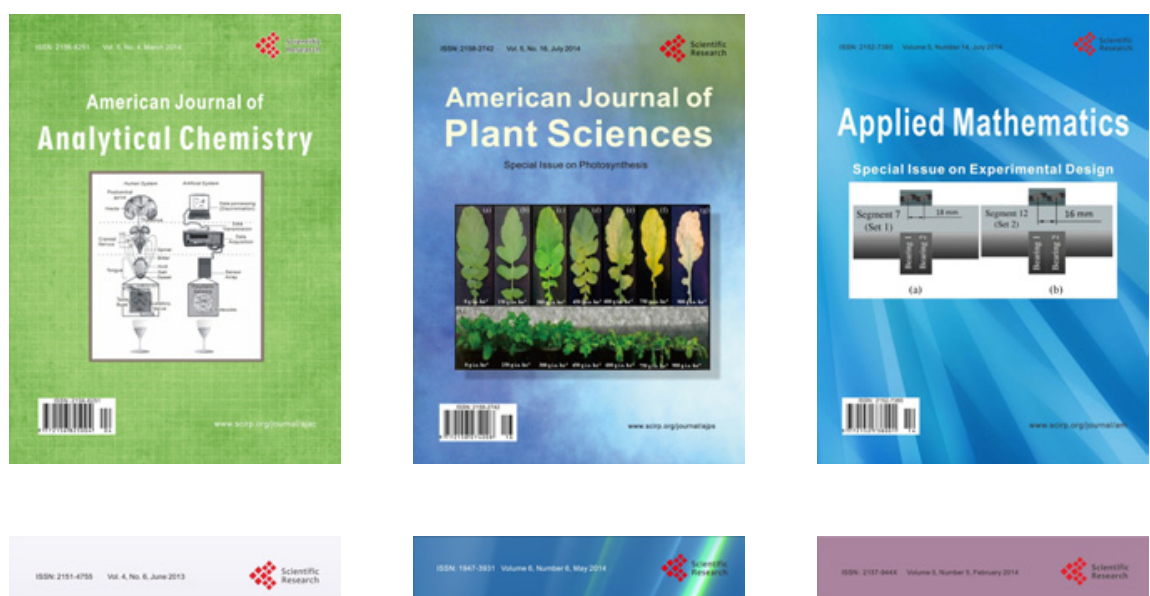

Creative Education
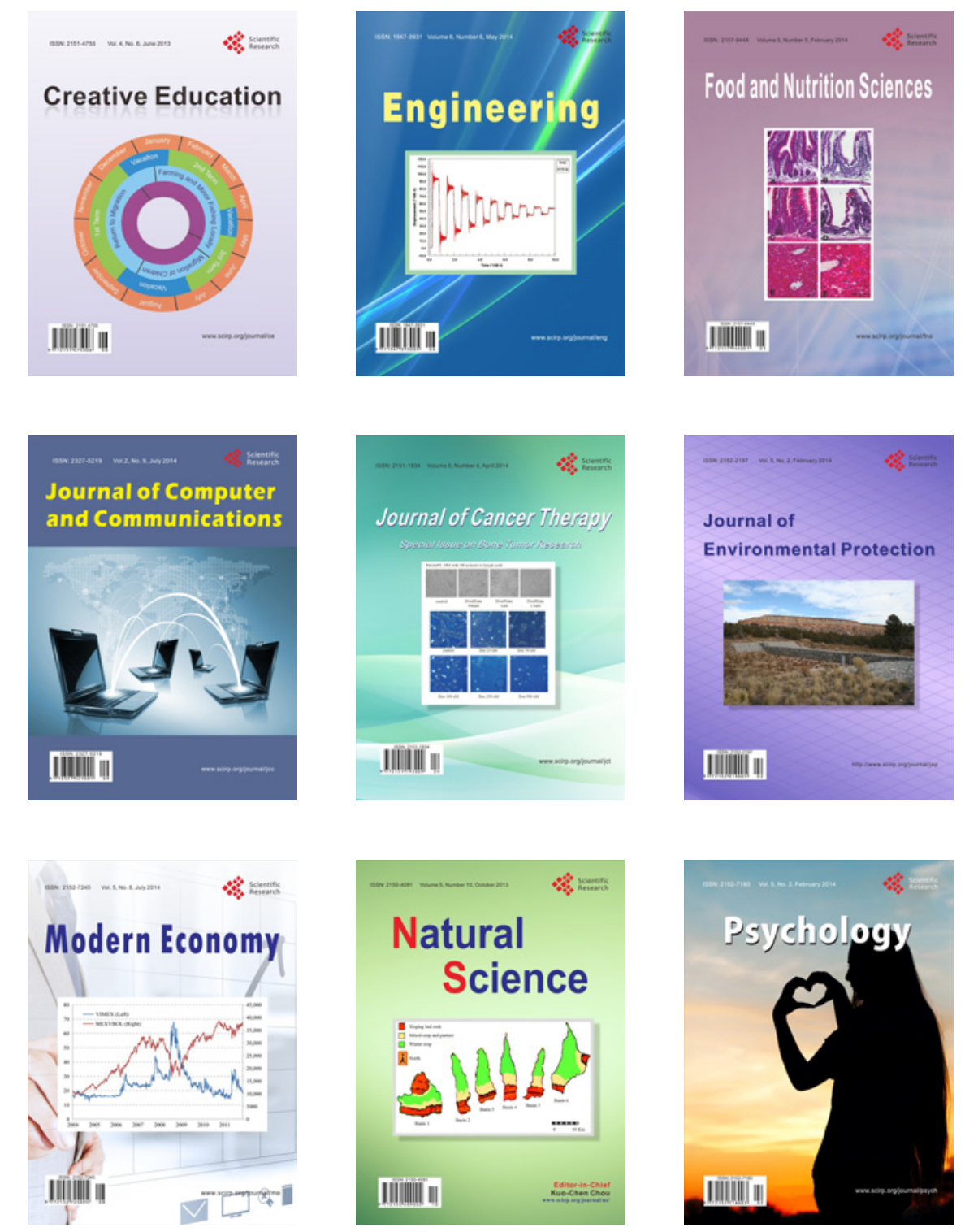